\title{
Elavult malakológiai nevezéktan negyedidôszaki és régészeti publikációkban: A tudományos név mögötti hipotézis
}

\author{
PÁll-Gergely Barna \\ ATK Növényvédelmi Intézet \\ e-mail: pallgergely2@gmail.com \\ ORCID ID: https://orcid.org/0000-0002-6167-7221
}

\section{Outdated malacological nomenclature in publications dealing with Quaternary and archaeological themes, respectively}

\begin{abstract}
The scientific names of species are not stable. They mostly change because new scientific results refute pre-existing hypotheses about the evolutionary relationships of organisms. The results of taxonomy and systematics only slowly (if ever) penetrate other disciplines. Reading Quaternary and archaeological publications - both in English and Hungarian — one can see that some scientific names are still used as if they are valid, despite having being incorrect for decades. In this paper I try to elucidate the background of this phenomenon, and suggest solutions.
\end{abstract}

Keywords: taxonomy, systematics, nomenclature, MolluscaBase, taxonomic databases

Összefoglalás

A fajok tudományos nevei nem állandóak. Elsôsorban azért változnak, mert az új tudományos eredmények megcáfolják az adott élőlény leszármazási viszonyaival kapcsolatban addig elfogadott hipotéziseinket. A rendszertan (taxonómia és szisztematika) eredményei csak lassan (ha egyáltalán) szivárognak be a többi tudományterületre. Hazai és nemzetközi negyedidőszaki és régészeti cikkeket olvasva bárki láthatja, hogy gyakran használnak olyan tudományos neveket, amelyek akár évtizedek óta helytelenek. Ebben az írásban a jelenség hátterét igyekszem megvilágítani, és javaslatot teszek a megoldásra is.

Tárgyszavak: taxonómia, szisztematika, nevezéktan, MolluscaBase, taxonómiai adatbázisok

A zoológiai nomenklatúra (nevezéktan) alapvetôen binominális, azaz minden faj tudományos neve két részből áll. Az első, a nagy kezdőbetűvel írandó génusznév, a második a kisbetűs fajnév (pl. Homo sapiens). Ezt a rendszert Carl LINNAEUS-nak (LINNÉ) köszönhetjük, aki ezt a sémát alkalmazta az állatok és növények latin neveire. Az ötlet annyira bevált, hogy a tudomány a mai napig ezt követi, és bár vannak próbálkozások a linnéi kategóriáktól való elszakadásra (pl. LAURIN 2010), nem valószínú, hogy más nevezéktani formát alkalmaznánk a fajok jelölésére. A binominális nómenklatúrát PODANI (2010) LINNÉ „óriási tévedésének” hívta, hiszen bár a rendszerezés alapegysége a faj, a nevezéktané a génusz. A fajnév (sapiens) ugyanis önmagában semmit nem ér, muszáj a génusznévhez (Homo) társítani, hogy egy konkrét fajt jelöljön. LiNNÉ védelmében annyit el kell mondanunk, hogy egytagú nevekkel nehezen lehetne úgy jelölni az eddig leírt közel 2 millió fajt, hogy ne legyenek azonos fajnevek (bár ez előfordul a jelenlegi rendszerben is).

Rendszertani alapelv, hogy a génuszoknak monofiletikusnak kell lenniük, tehát kizárólag olyan közel rokon fajokat tartalmazhatnak, amelyek egy közös őstől származnak. Továbbá minden génusznak tartalmaznia kell az összes fajt, amely a közös őstôl származik. A nem monofiletikus (tehát polifiletikus) génuszok vagy egyéb rendszertani kategóriák egyszerúen hibásak, ki kell őket javítani. A rokonsági viszonyok kibogozása természetesen nem egyszerú. Rendszertannal foglalkozó szakemberek generációinak munkája alakítja apró lépésenként az élővilág rendszerét, amely egyre tökéletesedik, tehát a faj feletti csoportok egyre inkább válnak monofiletikussá. A taxonómia, szisztematika és a rendszertan viszonyáról bővebben egy korábbi cikkemben írtam (PÁLL-GERGELY 2018), most erre nem térek ki. 
Az itt felvázoltakból az következik, hogy a gyakorlatban nem ritka, hogy a fajnév „,vezetéknevet cserél”, tehát más génuszba sorolódik, mint amelybe eredetileg leírták, vagy amibe évtizedeken keresztül tartozott. A rendszertani átrendeződéseknek a forradalmát éljük, hiszen a molekuláris filogenetikai módszerek mára rutinszerúvé váltak, és gyakran újraírják az eddig gondolt leszármazási viszonyokat. Íme, egy szemléletes példa. Magyarország talán leggyakoribb csigája, a pannon csiga majd' egy évszázadon keresztül Cepaea vindobonensis volt, azonban NEIBER et al. (2016) perdöntô molekuláris filogenetikai bizonyítékok alapján átsorolta a Caucasotachea génuszba, így a faj érvényes neve Caucasotachea vindobonensis lett. Természetesen nemcsak újonnan feltárt leszármazási viszonyok miatt változhat meg a tudományos név, hanem a nomenklatúra belsô szabályai miatt is. Például a közismert Trichia hispida (LINNAEUS, 1758) csigafaj neve azért változott meg Trochulus hispidus névre, mert a Trichia név egy bogárgénuszt is jelöl, így a csigagénusznak, amelyet később írtak le, új nevet kellett adni (ICZN 2004).

A negyedidôszaki és régészeti szakirodalomban (még a vezető nemzetközi folyóiratokban is) gyakran láthatóak olyan tudományos nevek, amelyek évtizedek óta nem helyesek. Ilyenek például a térségünk kvarter rétegeiből gyakran előkerülő Succinella oblonga (DRAPARNAUD, 1801) (helytelenül Succinea oblonga), Fruticicola fruticum (O. F. MüLLER, 1774) (helytelenül Bradybaena fruticum), Hessemilimax kotulae (WeSTERLund, 1883) (helytelenül Semilimax kotulai [sic!]), a már említett Trochulus hispidus és egyéb, korábban a Trichia génuszba sorolt fajok is. A Google Scholar adatbázisában 2016 után megjelent publikációkra keresve, 17 találatot kaptam a ,trichia hispida” + ,quaternary”, 29 találatot a „,succinea oblonga” + ,quaternary” és 22 találatot a „,cepaea vindobonensis” + ,quaternary” kulcsszavakra (a keresés 2020. április 16-án történt). A megtalált publikációk egy része nyilvánvalóan az idézett szakirodalom miatt került elő, azonban a talált cikkek nagy része valóban érvényesként használta az elavult neveket.

Miért érdekeljék a zootaxonómiával nem foglalkozó kutatókat (faunisták, ökológusok, geológusok, régészek, genetikusok stb.) az új rendszertani eredmények? A fajnevek mögötti tudományos tartalom megértése kell ehhez. Minden rendszertani egység (vagyis taxon) ugyanis nem más, mint egy hipotézis a leszármazási viszonyokról (WHEELER 2004). A „Cepaea vindobonensis” név mögött az a tartalom van, hogy a vindobonensis faj a többi Cepaea fajjal (hortensis és nemoralis) együtt monofiletikus egységet alkot. Ez a hipotézis megdőlt, hiszen kiderült, hogy a szeretett pannon csigánk a Kaukázus térségében élő Caucasotachea fajokkal alkot monofiletikus egységet, a Cepaea fajoknak viszont csak távolról rokona. A Cepaea vindobonensis név innentől kezdve nem más, kissé sarkítva, mint tudománytörténeti érdekesség. A nevezéktan naprakészen tartása a csigafajokról elnevezett negyedidőszaki biozónákra is érvényes. Ha egy csigafaj latin neve megváltozik, ezt a biozóna nevének is követnie kéne. Remek párhuzam erre a növénytársulások nevezéktanának kódexe, amely ugyanígy jár el, tehát ha egy növényfaj tudományos neve megváltozik, az változást jelent az adott növényfajról elnevezett növénytársulásban is (THEURILlat et al. 2020).

Felmerül a probléma, hogyan lehet naprakésznek lenni, ha gyakran változik a rendszer és ennek következtében a nevezéktan. Ha egy negyedidőszaki malakofaunát közlő mú egy adott monografikus munkát (könyvet vagy cikket) idéz, azzal csak az adott idôpillanatban helyesnek tartott latin neveket veheti át, tehát az adott munka utáni eredményeket nem. Nyilvánvaló, hogy minden egyes fajnév „,vadászata” a taxonómiai szakirodalomban nehezen kivitelezhetô. Erre kínálnak megoldást az állandóan naprakészen tartott honlapok, adatbázisok. Elsôsorban a www.molluscabase.org (MoLlusCABASE eds 2020) adatbázist tudom javasolni, amely pár éven belül az összes recens és fosszilis puhatestú fajt fogja tartalmazni, lehetôség szerint az eredeti leírások idézésével együtt. Emellett például a cseh és szlovák puhatestú-fauna nevezéktanát is folyamatosan frissítik a következő honlapon: http://mollusca.sav.sk/malacology/checklist.htm.

Szeretném leszögezni: természetesen a régészeti vagy szedimentológiai munkák tudományos értékét nem csökkenti, ha azok elavult tudományos nevezéktant használnak. Végeredményben a héjak helyes meghatározása a legfontosabb. Az itt felvázolt megjegyzésem stilisztikai jellegúnek tûnik, és talán az is. Mindemellett, mivel a nevezéktani változásokat követni a fenti megoldásokkal nem kíván jelentősebb erőfeszítést, és a rendszertani szakirodalomban jelenlévővel ,párhuzamos” negyedidőszaki/ régészeti nevezéktant semmi nem indokolja, javaslom az új szisztematikai eredmények használatát a publikációk igényességének növelése szempontjából.

\section{Köszönetnyilvánítás}

Szeretnék köszönetet mondani LENGYEL Attilának a növénytársulások nevezéktanával kapcsolatos szakirodalomért. 


\section{Irodalom — References}

ICZN 2004: Opinion 2079 (Case 2926). Trichia Hartmann, 1840 (Mollusca, Gastropoda): proposed conservation; and Trichiinae Ložek, 1956 (Gastropoda): proposed emendation of spelling to Trichiainae, so removing the homonymy with Trichiidae Fleming, 1821 (Insecta, Coleoptera) not approved. — Bulletin of Zoological Nomenclature 61/3, 177-181.

LAURIN, M. 2010: The subjective nature of Linnaean categories and its impact in evolutionary biology and biodiversity studies. Contributions to Zoology 79/4, 131-146. https://doi.org/10.1163/18759866-07904001

MolluscaBAse eds 2020: MolluscaBase. — Accessed at http://www.molluscabase.org on 2020-04-17.

NeIBER, M. T., SAGORNY, C. \& HAUSDORF, B. 2016: Increasing the number of molecular markers resolves the phylogenetic relationship of 'Cepaea' vindobonensis (Pfeiffer 1828) with Caucasotachea Boettger 1909 (Gastropoda: Pulmonata: Helicidae). — Journal of Zoological Systematics and Evolutionary Research 54/1, 40-45. https://doi.org/10.1111/jzs.12116

PÁLl-Gergely B. 2018: Szemléletváltás szükséges a taxonómia és szisztematika viszonyáról és meghatározásáról. —Magyar Tudomány 179/7, 1083-1093. https://doi.org/10.1556/2065.179.2018.7.15

PodAni J. 2010: Evolúció, törzsfa, osztályozás. — Magyar Tudomány 171/10, 1179-1192.

Theurillat, J.-P., Willner, W., Fernández-González, F., Bültmann, H., Čarni, A., Gigante, D., Mucina, L. \& Weber, H. 2020: International Code of Phytosociological Nomenclature. (4th edition.) — Applied Vegetation Science. https://doi.org/10.1111/ avsc. 12491

WheELer, Q. 2004: Taxonomic Triage and the Poverty of Phylogeny. — Philosophical Transactions of The Royal Society, London B, Biological Sciences 359, 571-583. https://doi.org/10.1098/rstb.2003.1452

Kézirat beérkezett: 2020. 06. 16. 